\title{
Learning From Home in Early Childhood Education Students
}

\author{
Yuni Herlina $^{1 *}$, Muhammad Kristiawan ${ }^{2}$, Dwi Anggraini ${ }^{3}$ \\ ${ }^{1}$ Tarbiyah and Tadris Department, State Institute for Islamic Studies of Bengkulu, Indonesia \\ ${ }^{2}$ Education Doctoral Study Program, University of Bengkulu, Indonesia \\ ${ }^{3}$ Primary School Teacher Education Study Program, University of Bengkulu, Indonesia \\ ${ }^{*}$ Corresponding author.Email: yuni.dellia@gmail.com
}

\begin{abstract}
The study aims to investigate the responses of parents who have early childhood while accompanying children to learn from home during the Covid-19 pandemic in accordance with the government policies regarding learning from home. The research method was carried out by a survey through Google form that was that was filled in by parents of PAUD Dellia Creative School students in Bengkulu City, with a child age range of 2 years 10 months up to 6 years 2 months. The data collection technique used was a questionnaire. The questionnaire was distributed from September $28^{\text {th }}$, 2020 to October, 12 $2^{\text {nd }}$, 2020. The questionnaire was distributed to 38 respondents containing 6 questions about the problems of parents in guiding children to study at home. The survey results show that $81.6 \%$ of parents feel that the Home Learning policy for PAUD children is difficult, $86.8 \%$ do not understand the right methods to assist children to learn, $81.6 \%$ do not have facilities for learning, $84.2 \%$ are difficult in motivating the children to learn, $65.8 \%$ prioritizing children in higher education, and $55.3 \%$ availability of time to guide children to study at home. This condition is likely to continue as long as learning is carried out at home online in accordance with government policy.
\end{abstract}

Keywords: Parents, Learning From Home, the Covid-19 Pandemic, Early Childhood.

\section{INTRODUCTION}

At the beginning of March 2020, the Indonesian people were shocked by an announcement issued by the President of the Republic of Indonesia, that there were 2 Indonesian citizens who had been exposed to Covid-19 (Coronavirus Disease-2019). This very dangerous virus finally entered Indonesia. This deadly virus has allegedly started to become epidemic since December 2019 and has now spread rapidly throughout the world. Hundreds of countries have been infected and hundreds of thousands of people have died from this virus. Since it was announced that this virus had started to become epidemic in Indonesia, the spread of the virus was increasing day by day. The number of patients exposed to Covid-19 is increasing, hospitals and medical personnel are quite overwhelmed in facing the booming number of patients, so that patients cannot be handled properly. Covid-19 is the leading cause of death. Finally, the Indonesian Government determined that the Covid-19 outbreak was a National Disaster [1].
The Covid-19 pandemic has changed almost all aspects of human life, starting from the health, economic, and social aspects including education. The people are required to change their lifestyle. Activities carried out by means of direct interaction between humans must be reduced or even eliminated. This is related to several policies taken by the government to break the chain of spreading Covid-19. In the world of education, the Government, in this case the Ministry of Education and Culture, has issued several circular letters in order to prevent the spread of Covid-19. Among them are Circular Number 2 of 2020 concerning Prevention and Handling of Covid-19 in the Ministry of Education and Culture and Circular Number 3 of 2020 concerning Prevention of Covid-19 in the Education Unit. Furthermore, on March 24, 2020 the government issued Circular No. 4 of 2020 concerning the Implementation of Education in the Covid-19 Emergency Period. This circular from the Minister of Education and Culture addressed to governors and regents / mayors throughout Indonesia consists of two pages containing six important points. These points are related to the National 
Examination, the learning process from home, School Exams, class promotion, New Student Admissions, and School Operational Assistance (BOS) funds.

With the issuance of this circular, there have been major changes in the implementation of the teaching and learning process. All local governments issue circular letters regarding the implementation of learning during the pandemic period. The learning process that was originally carried out face-to-face between the teacher and students has changed drastically online. The direct interaction that occurs between teacher-student, student-student and teacher is lost. All learning processes are carried out using a face-to-face remote system. All educational institutions carry out the learning process which is carried out from home using the internet media. Changes in the implementation of this learning process occur at all levels of education, from Early Childhood Education (PAUD) to Higher Education. This is reinforced by the issuance of the government Circular No. 15 of 2020 concerning Guidelines for Implementing Learning from Home during Disaster Emergency. Learning From Home (BDR) activities are carried out to provide meaningful learning experiences for students, without being burdened by demands to complete all curriculum achievements and focus on life skills education, including regarding the Covid-19 pandemic. Learning materials are inclusive in accordance with the age and level of education, cultural context, character and type of specificity of students [2].

The policy for implementing Learning From Home has received pros and cons from the community, including teachers, students and parents. Teachers, students and parents are not yet ready with this online learning process. Various problems arise in its implementation. Teachers who have been teaching by interacting directly with students are forced to carry out the learning process through online. The teacher must make an attractive learning design so that the learning process can run well and the material provided is conveyed, while parents must be able to position themselves as a teacher in accompanying children to learn from home. This problem occurs in almost all teachers and parents at all levels of education.

The implementation of Learning From Home in Early Childhood Education (PAUD) raises even more complex problems, where early childhood requires special attention and methods in educating them. A teacher must prepare and use learning that can develop all aspects of a child's development as a whole, not only focus on one development [3]. By online system, the teachers will find it difficult to provide stimulation for children, especially since early childhood has a concentration period that is very much determined by age, the smaller the child's age the lower the concentration level, so that the online learning process is difficult to apply to early childhood.

The early childhood learns through play. Parents have an important role in the implementation of learning from home in PAUD, where parents must accompany and provide support to children while playing and learning in accordance with the learning plan that has been made by the teacher. This means that the parents must have the ability to stimulate the children's development, have good communication techniques, and prepare appropriate play materials so that the children are interested in participating for playing activities.

In assessing the children's development, the teachers rely heavily on documentation of children's development achievements while playing at home sent by parents, either in the form of photos or videos. If parents do not send this documentation, it will be difficult for the teacher to assess the child's development. Assessment of child development will be a reference for PAUD teachers in planning the next lesson.

\section{METHOD}

This study used a survey research method with a descriptive quantitative approach. The data collection technique is a questionnaire that is distributed using Google Form online to parents of Dellia Creative School PAUD students, with a range of ages of children 2 years 10 months up to 6 years 2 months. 
The distribution of questionnaires was carried out from September $28^{\text {th }}, 2020$ to October $12^{\text {nd }}$, 2020. The questionnaire was distributed to 38 respondents containing 6 questions about the problems of parents in guiding the children to study at home. This data was analyzed by using a percentage technique with the following formula.

$$
Y=\frac{\Sigma Y}{N} \times 100 \%
$$

\section{RESULT AND DISCUSSION}

\subsection{Result}

The questionnaire distributed contains seven questions regarding the difficulties of parents in accompanying the children to study at home during the pandemic. Accroding to 38 respondents, 11 of them have children who are at the education level in PAUD and 1 person did not give an answer. From the responses of the parents, it shows that 31 respondents stated that the government policy regarding to Learning From Home for PAUD children was difficult, 6 respondents answered normally and 1 person did not give an answer.

Table 1.

Age Range of Respondents' Children

\begin{tabular}{|c|c|c|}
\hline No & Age Range & $\begin{array}{c}\text { Number of } \\
\text { Children }\end{array}$ \\
\hline 1 & 2 year $-2,9$ year & 1 \\
\hline 2 & 3 year $-3,9$ year & 13 \\
\hline 3 & 4 year $-4,9$ year & 11 \\
\hline 4 & 5 year $-5,9$ year & 5 \\
\hline 5 & 6 year $-6,9$ year & 6 \\
\hline 6 & Without Explanation & 2 \\
\hline & Total & 38 \\
\hline
\end{tabular}

Table 2.

Percentage of Responses to Government Policies

Regarding Learning from Home for Early

Childhood

\begin{tabular}{|l|l|c|c|c|}
\hline \multirow{2}{*}{ No } & Aspect & $\begin{array}{l}\text { Number of Respondents } \\
\text { Trouble } \\
\text { some }\end{array}$ & $\begin{array}{l}\text { Ordi } \\
\text { nary }\end{array}$ & $\begin{array}{l}\text { No } \\
\text { respon } \\
\text { se }\end{array}$ \\
\hline 1 & $\begin{array}{l}\text { Government } \\
\text { Policy } \\
\text { Regarding } \\
\text { Learning } \\
\text { From Home }\end{array}$ & 31 & 6 & 1 \\
\hline Percentage (\%) & 81,6 & 15,8 & 2,6 \\
\hline
\end{tabular}

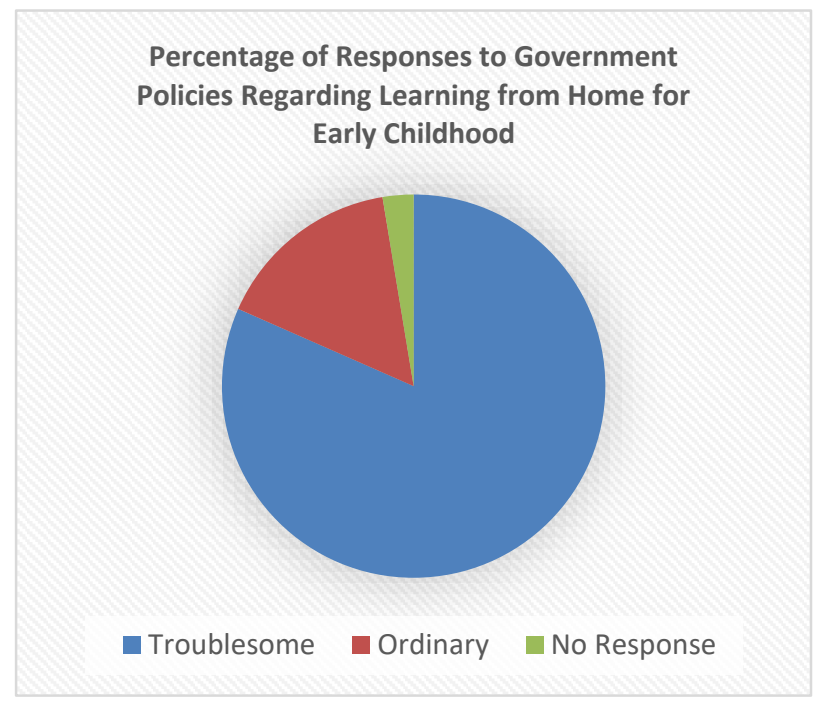

In the aspect of learning methods, 33 respondents stated that they did not understand the appropriate method for teaching at home. The reasons they gave were because they did not have time to accompany the children to study because they had to work until afternoon, so it was difficult to understand how the early childhood to learn. They have different ways of teaching with elementary school children. Their children were not serious and difficult to learn because they wanted to play, difficult to organize themselves and feel lazy. The children were lazy to study with parents at home. The following is a diagram for parents' understanding of home learning methods for early childhood.

Table 3.

Percentage of Parents' Understanding Responses to Appropriate Methods for Early Childhood

\begin{tabular}{|l|l|c|c|}
\hline No & \multicolumn{2}{|c|}{ Aspect } & \multicolumn{2}{|c|}{$\begin{array}{c}\text { Number of } \\
\text { Respondents }\end{array}$} \\
\cline { 3 - 4 } Yes & No \\
\hline 1 & $\begin{array}{l}\text { Not Understanding } \\
\text { the Right Methods } \\
\text { for } \\
\text { Childhood Early }\end{array}$ & 33 & 5 \\
\hline & Percentage (\%) & 86,8 & 13,2 \\
\hline
\end{tabular}




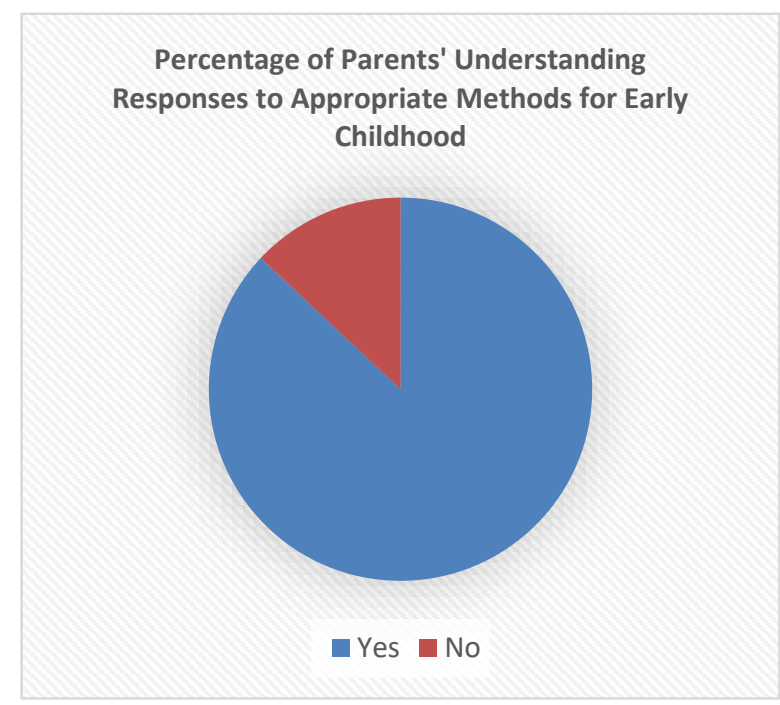

The next aspect showed that 18 respondents stated that they did not have facilities that support online learning at home. The reason is that the parents only have one cellphone used for work and this is prioritized for their older siblings who are at the elementary school level. For the motivation aspect, 32 respondents stated that it was difficult to motivate the children to learn while doing the Learning From Home program. The reason is that the children do not focus to do not want to learn, do not want to be forced and difficult to be controlled.

Table 4. Percentage of Parents' Responses to the Availability of Learning Facilities

\begin{tabular}{|l|l|c|c|}
\hline No & \multicolumn{2}{|c|}{ Aspect } & \multicolumn{2}{|c|}{$\begin{array}{c}\text { Number of } \\
\text { Respondents } \\
\text { Don't } \\
\text { Have }\end{array}$} & Have \\
\hline 1 & $\begin{array}{l}\text { Ketersediaan } \\
\text { Fasilitas } \\
\text { Belajar }\end{array}$ & 31 & 6 \\
\hline Percentage (\%) & 81,6 & 15,8 \\
\hline
\end{tabular}

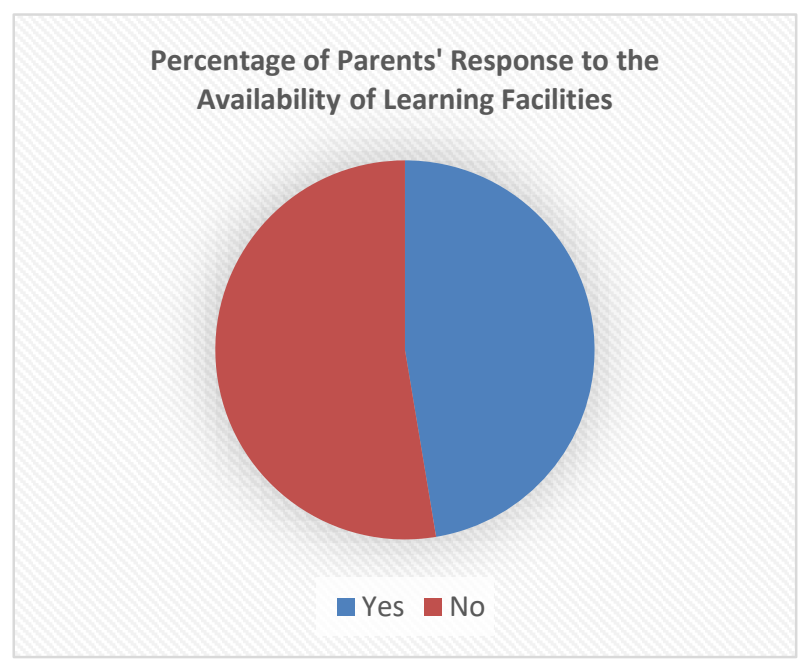

Table 5.

Percentage of Difficulty Responses to Motivate Children to Learn at Home

\begin{tabular}{|c|c|c|c|c|}
\hline \multirow[b]{2}{*}{ No } & \multirow[b]{2}{*}{ Aspect } & \multicolumn{3}{|c|}{ Number of Respondents } \\
\hline & & Yes & No & $\begin{array}{c}\text { No } \\
\text { Response }\end{array}$ \\
\hline 1 & $\begin{array}{l}\text { Difficulty } \\
\text { Motivating } \\
\text { Children to } \\
\text { Learn at } \\
\text { Home }\end{array}$ & 32 & 5 & 1 \\
\hline \multicolumn{2}{|c|}{ Percentage $(\%)$} & 84,2 & 13,2 & 2,6 \\
\hline
\end{tabular}

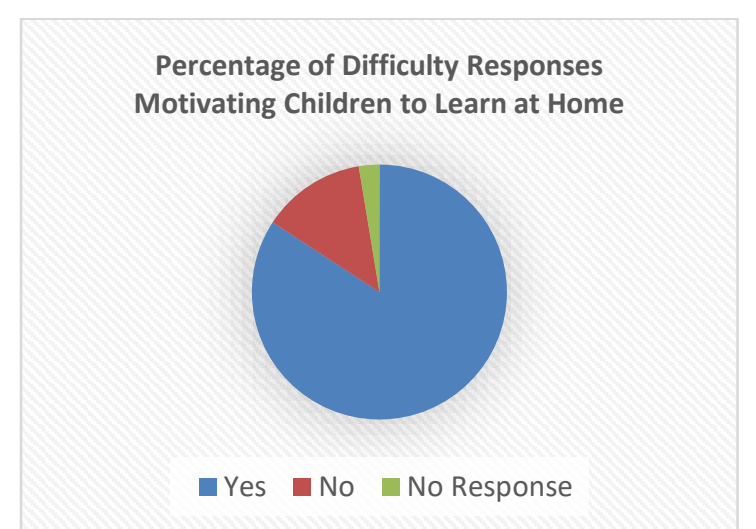

Furthermore, 25 respondents stated that they would prioritize accompanying their children who are at the elementary school level compared to other education levels and 3 respondents stated that they prioritized accompanying children who were at the PAUD level, and the rest did not provide answers. In the last aspect, 21 respondents stated that they did not have enough time to accompany children to study at home. 
The following is a table of the percentage of questionnaire results obtained during the study.

Table 6.

Percentage of Parents' Response to Putting Children First in Higher Education

\begin{tabular}{|l|l|c|c|c|}
\hline \multirow{2}{*}{ No } & Aspect & \multicolumn{3}{|c|}{ Number of Respondents } \\
\hline 1 & $\begin{array}{l}\text { Yutting } \\
\text { Yes }\end{array}$ & No & $\begin{array}{c}\text { No } \\
\text { Response }\end{array}$ \\
\hline $\begin{array}{l}\text { Higher } \\
\text { Education } \\
\text { Levels }\end{array}$ & 25 & 3 & 10 \\
\hline Percentage (\%) & 65,8 & 7,9 & 26,3 \\
\hline
\end{tabular}

Percentage of Parents Response to Putting Children First in Higher Education

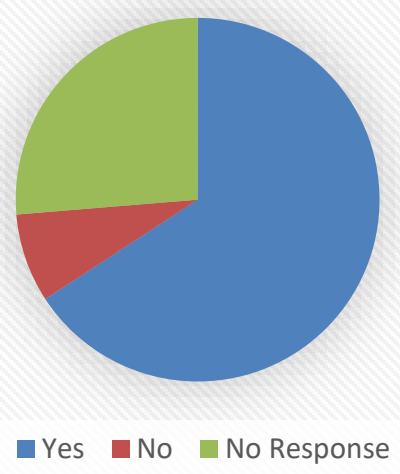

Table 7.

Percentage of Response Time Availability to Guide Children to Study at Home

\begin{tabular}{|l|l|c|c|}
\multirow{2}{*}{ No } & \multicolumn{2}{|c|}{ Aspect } & \multicolumn{2}{c|}{$\begin{array}{c}\text { Number of } \\
\text { Respondents }\end{array}$} \\
\cline { 3 - 4 } 1 & $\begin{array}{l}\text { Yes } \\
\text { Have Time } \\
\text { To Guide } \\
\text { Children } \\
\text { Learn At At } \\
\text { Home }\end{array}$ & 21 & 17 \\
\hline \multicolumn{2}{|l|}{ Percentage (\%) } & 55,3 & 44,7 \\
\hline
\end{tabular}

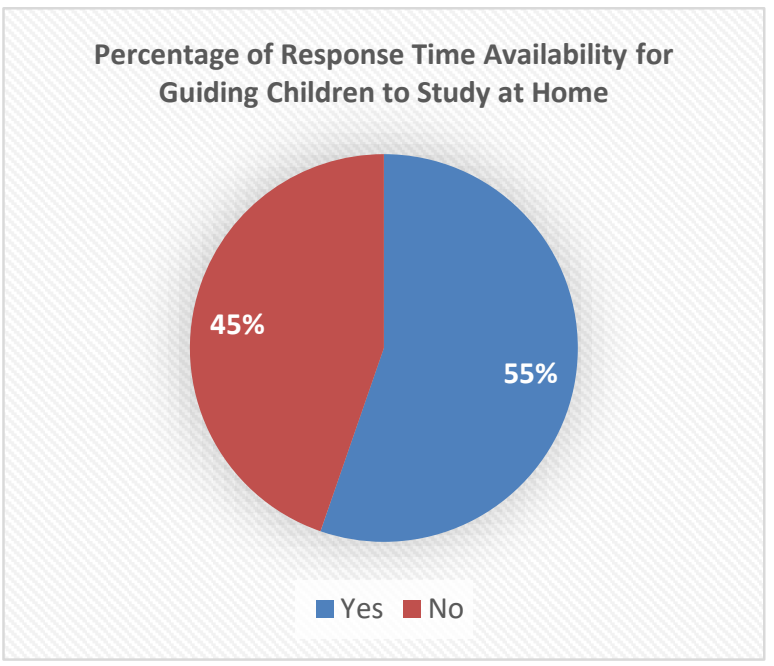

\subsection{Discussion}

Based on Law no. 20 of 2003 concerning the National Education System, Early Childhood education is a coaching effort carried out by providing educational stimuli to children from birth to six years of age. Early childhood education aims to help the physical and spiritual growth and development of children so that they are ready to enter further education. Early childhood education aims to help achieve six aspects of development in children.

Early childhood learns through play. Children's play activities are not just playing, but are a means for children in the learning process to get direct experience in their lives. According to Piaget, real play is very important for learning in early childhood [4] [5]. Children will get information and knowledge from play activities which are obtained by seeing, hearing, feeling and feeling. In playing, children need intervention and support from adults around them, especially teachers and parents.

With the stipulation of the learning process in early childhood education to be carried out online, it cannot reach the learning needs of children. Learning with this online system is a big problem for teachers in stimulating the children's development. Playing activities require the direct interaction between the children and teachers. When it is done online, the teacher cannot provide support to children while playing. Because 
meaningful play is when the children get support from adults around them [6].

The implementation of Learning From Home in early childhood education really requires the role of parents. Parents must be involved in children's play activities. In addition to accompanying and providing support when children play, parents are also expected to be able to document every play activity carried out by the child, then send it to the teacher regularly in the form of photos and videos. This documentation is used as material by the teacher to determine the level of achievement of children's development and determine the next lesson planning.

The teacher must compile a learning plan that is interesting, fun, utilizes existing materials at home and play activities that are easy to do at home, so it makes easy for parents to accompany them. Imagine if the parents do not want to be involved in the children's play activities or parents do not send documentation of children's activities? The teacher will find it difficult to assess the child's development and the teacher cannot make plans for the next lesson. The strategy that can be used by the teacher is to design a lesson plan and then send it to the parents, then the parents carry out the process at home with the child.

Various plans for play activities are designed by the teacher, including methods and tools/materials to make it easier for parents to assist children in learning at home. However, this method raises new problems. Not a few parents complain when accompanying their children to study at home. In fact, parents have asked for schools to be reopened so that their children can participate in the learning process at school.

Learning with online media is a challenge for early childhood education teachers. In addition to prepare the lesson plans, early childhood education teachers must also educate parents so that they can assist children in learning at home. The number of problems expressed by parents was allegedly due to the unpreparedness of parents in accompanying children to learn from home. So far, the parents fully submit their children's education to educational institutions, but currently parents have to do it.
The obstacles experienced by parents in accompanying the children to study at home include a lack of understanding of the material by parents, the difficulties for parents in fostering the children's interest in learning, not having enough time to accompany children because they have to work, impatient in accompanying children while studying at home, difficulties parents in operating gadgets, and obstacles related to internet service coverage. Therefore, in this online implementation, it turns out that parents have many obstacles in accompanying children to study at home.

In assisting children to learn from home, parents do not understand the proper teaching methods. This condition sometimes makes parents impatient and exhausted, as a result, children become victims of their parents' frustration. Some children get physical and psychological violence from their parents. Parents feel bored with learning carried out at home and the Work From Home Policy that is implemented, this triggers impatience of parents in accompanying children to learn and play [7].

The problems above are caused by parents who do not understand the meaning of learning in early childhood, where the children learn through playing. Playing that is done by children must be in ways that are fun and without coercion. Playing is an activity that is done for fun and without considering the end result and is done voluntarily, without coercion or pressure from outside [8]. Adults who accompany children while playing must understand very well the tools and materials used for play, the arrangement of the play environment, the support provided to children when playing and documenting the play activities carried out by children.

Difficulty in motivating children to learn is also a complaint of parents in assisting children to study at home. This is of course a big obstacle in stimulating children's development, considering that learning motivation plays a very important role in the learning process [9].

When accompanying children to study at home, parents' expectations often do not match 
with the children achievement. Currently there are still parents who have difficulty in creating a pleasant atmosphere, building emotional closeness with their children [10]. Parents often impose their desires on their children, and when it doesn't materialize, parents will blame their children. In the early childhood education, parents really want their children to be able to read, write and count quickly, even though it is not the time for early childhood to be taught formally calistung, except in a fun way without coercion [6]. This certainly eliminates the children's interest in learning and children are not motivated to follow activities directed by parents. Early childhood should play based on their interests. When the children are forced to do activities that are not in accordance with their interests, the stimulation to aspects of child development is hampered.

The problems faced by parents are not only seen from the aspect of teaching methods and parents' understanding of the material that must be delivered, but also some parents who have children at different levels of education, ultimately have to determine which child's choice is a priority to get assistance in learning at home. School tasks that have to be done by older siblings get more serious attention and take up enough time for parents. While, the early childhood is not considered too important for learning, even though the stimulation given to the early childhood must continue to be carried out by parents in seeking the development of all existing potential in the child.

Based on research conducted by many experts, about $50 \%$ of adult intelligence capabilities have occurred when the child was 4 years old, $80 \%$ there has been a rapid development of brain tissue when the child was 8 years old and reached its peak when the child was 18 years old, and after even though the improvement in nutrition will not affect cognitive development [6]. From those explanation , it can be concluded that early childhood education is very important, because the importance of this age is called the golden age. The developments that occur at this age cannot be repeated in the future.

The parents who work admit that they do not have time to accompany their children to study at home. The routines in the office force parents to go home in the afternoon and arrive home in tired. As a result, they cannot accompany their children to study at home. Whereas, the learning from home policy that was issued by the government really needs a support from parents, considering that parents are the first and foremost teachers of children. During the Covid 19 pandemic, the children cannot interact with their teachers, so it is hoped that parents can replace the role of teachers at home as facilitators of children while learning.

During the Covid-19 pandemic, the early childhood education teachers created many strategies in the learning process, so that stimulation carried out on children did not stop even though the child did not come to the early childhood education. In addition, to create the interesting learning activities that are entrusted to parents to carry it out at home, the teacher occasionally also holds face to face with the child virtually either using the zoom meeting application media or video call media using the WhatsApp application. Looking at some of the learning strategies carried out by the teacher above, it can be ascertained that the role of parents is needed, considering that all of the above activities require assistance from parents.

The conditions in the field indicate that parents who are not involved in children's activities while playing cannot convey information on their child's development to the teacher. So that the teacher finally has difficulty in assessing the achievement of child development which results in difficulties for teachers in planning further learning and difficulties in preparing child development reports.

Another problem expressed by parents in accompanying children to learn from home during the Covid-19 pandemic is the lack of facilities and infrastructure to support children's learning activities. There are parents who admit that they only have one android, do not have a laptop or computer, and even admit they don't have an android cellphone. This condition makes it difficult for parents to accompany their children to study at home. While Android cellphones are needed to communicate with teachers. Parents can 
send photos or videos of children's activities by using their Android cellphone.

Apart from that, he also complained about the need for internet connection, considering that parents must have a quota every day to support their children learning from home. The need for internet connection is felt to be burdensome because there are parents who have experienced a decrease in income during the Covid-19 pandemic. Although currently the government has issued an internet quota facility assistance policy, it is felt that this is not sufficient considering the need for a larger internet quota. The obstacle for parents in providing online education facilities is the use of the internet network which requires a lot of money [11]. Internet network coverage is also an obstacle for parents. One of the obstacles for parents in accompanying their children to study at home is the reach of the internet network [12].

\section{CONCLUSION}

Based on research that has been conducted, $81.6 \%$ of parents feel that the Home Study policy for PAUD children is difficult, $86.8 \%$ do not understand the right method in assisting children to learn, $81.6 \%$ do not have facilities for learning, $84.2 \%$ it is difficult to motivate children to learn, $65.8 \%$ prioritize children in higher education, and $55.3 \%$ availability of time to guide children to study at home. This condition is likely to continue as long as learning is carried out at home online in accordance with government policy. The results of this study are expected to provide input to the government and managers of PAUD Dellia Creative School to find the right solution so that the problems of Learning from Home for early childhood can be handled properly.

\section{ACKNOWLEDGMENT}

This research was supported by the management of PAUD Dellia Creative School and all parents of Dellia Creative School PAUD students who had become respondents.

\section{REFERENCES}

[1] E. Pranita, "Diumumkan Awal Maret, Ahli: Virus Corona Masuk Indonesia dari Januari," Kompas.COm, 11 Mei 2020. [Online].
Available:

https://www.kompas.com/sains/read/2020/05/11 /130600623/diumumkan-awal-maret-ahli--viruscorona-masuk-indonesia-dari-januari. [Accessed 25 Oktober 2020].

[2] P. W. Kemdikbud, "Kemendikbud Terbitkan Pedoman Penyelenggaraan Belajar dari Rumah," Kementerian Pendidikan dan Kebudayaan, 29 Mei 2020. [Online]. Available: https://www.kemdikbud.go.id/main/blog/2020/0 5/kemendikbud-terbitkan-pedomanpenyelenggaraan-belajar-dari-rumah. [Accessed 28 Oktober 2020].

[3] S. Aisyah, T. Chandrawati, S. Tatminingsih, D. Novita, D. Setiawan, U. L. Budi, M. Amini, Perkembangan dan Konsep Dasar Pengembangan Anak Usia Dini, Tangerang Selatan: Universitas Terbuka, 2014.

[4] M. S. Tedjasaputra, Bermain, Mainan, dan Permainan, Jakarta: PT. Grasindo, 2001.

[5] T. Musfiroh, Bermain dan Permainan Anak, Jakarta: Universitas Terbuka, 2014.

[6] D. PAUD, Cara Belajar Anak Usia Dini, Jakarta: Kementerian Pendidikan dan Kebudayaan, 2018.

[7] Tabiin, "Problematika Stay At Home Pada Anak Usia Dini Di Tengah Pandemi," Jurnal Golden Age, vol. 4, no. 1, pp. 190-200, 2020.

[8] T. Musfiroh, Teori dan Konsep Bermain, Jakarta: Univeristas Terbuka, 2014.

[9] A. Master \& G. M. Walton, "Minimal Groups Increase Young Children's Motivation and Learning on Group-Relevant Tasks," Child Development, vol. 84, no. 2, pp. 737-751, 2013.

[10] F. Rohayani, "Menjawab Problematika Yang Dihadapi Anak Usia Dini Di Masa Pandemi Covid-19," QAWWAM: Journal For Gender 
Mainstreaming, vol. 14, no. 1, pp. 29-50, 2020.

[11] K. Jones \& R. Sharma, Imagining A Future For Online Learning, New York, 2019.

[12] A. Wardani \& Y. Ayriza, "Analisis Kendala Orang Tua dalam Mendampingi Anak Belajar di Rumah Pada Masa Pandemi Covid-19," Jurnal Obsesi, vol. 5, no. 1, pp. 772-782, 2021. 